\title{
Petrotoga mexicana sp. nov., a novel thermophilic, anaerobic and xylanolytic bacterium isolated from an oil-producing well in the Gulf of Mexico
}

\author{
Elizabeth Miranda-Tello, ${ }^{1}$ Marie-Laure Fardeau, ${ }^{1}$ Pierre Thomas, ${ }^{1}$ \\ Florina Ramirez, ${ }^{2}$ Laurence Casalot, ${ }^{1}$ Jean-Luc Cayol, ${ }^{1}$ Jean-Louis Garcia ${ }^{1}$ \\ and Bernard Ollivier ${ }^{1}$
}

Correspondence

Bernard Ollivier

ollivier@esil.univ-mrs.fr

\author{
${ }^{1}$ IRD, UR 101 Extrêmophiles, IFR-BAIM, Universités de Provence et de la Méditerranée, ESIL, \\ Marseille, France \\ ${ }^{2}$ Laboratorio de Tratamiento de Aguas Residuales, Universidad Autónoma Metropolitana, \\ México, DF, Mexico
}

\begin{abstract}
A novel anaerobic, thermophilic, xylanolytic, motile rod-shaped bacterium with a sheath-like outer structure (toga) was isolated from a Mexican oil well in the Gulf of Mexico. Strain MET12 ${ }^{\top}$ was a Gram-negative bacterium, reducing elemental sulfur, thiosulfate and sulfite to hydrogen sulfide. Its optimum growth conditions were $55^{\circ} \mathrm{C}, \mathrm{pH} 6 \cdot 6,3 \% \mathrm{NaCl}$ and $0.15 \% \mathrm{MgCl}_{2} \cdot 6 \mathrm{H}_{2} \mathrm{O}$. The DNA G $+\mathrm{C}$ content was $36 \cdot 1$ mol\%. Phylogenetically, strain MET12 ${ }^{\top}$ was related to members of genus Petrotoga, with similarities to Petrotoga mobilis, Petrotoga sibirica, Petrotoga miotherma and Petrotoga olearia varying from $97 \cdot 6$ to $98 \cdot 8 \%$. However DNA-DNA relatedness values between these species and strain MET12 ${ }^{\top}$ were lower than $70 \%$. As strain MET12 ${ }^{\top}$ $\left(=\mathrm{DSM} 14811^{\top}=\mathrm{CIP} 107371^{\top}\right)$ was genomically and phenotypically different from existing Petrotoga species, it is proposed as the type strain of a novel species, Petrotoga mexicana sp. nov.
\end{abstract}

Anaerobes have always been considered as the dominant micro-organisms of petroleum reservoirs (Magot et al., 2000). Among them, fermentative bacteria constitute an important microbial community of the oilfield environment. Thermophilic isolates are the most studied, probably because (i) most oil reservoirs occur at depths where the temperature is high and (ii) thermophiles possess thermostable enzymes of great interest in industrial processes. Stetter et al. (1993) provided evidence of the presence of Thermotoga strains, members of the order Thermotogales, in oilfields. The isolation of Thermotoga elfii, Thermotoga subterranea and Thermotoga hypogea from such ecosystems was reported shortly afterwards (Fardeau et al., 1997a; Jeanthon et al., 1995; Ravot et al., 1995a). Microbial studies on various hot oil reservoirs throughout the world have provided evidence of the importance of micro-organisms morphologically and physiologically close to other members of Thermotogales, namely Fervidobacterium, Thermosipho, Geotoga and Petrotoga (Grassia et al., 1996; Magot et al., 2000). However, no Fervidobacterium species originating from oilfield reservoirs has been characterized so far. Davey et al. (1993) first reported the presence of microorganisms belonging to the genera Geotoga and Petrotoga in petroleum reservoirs located in Oklahoma and Texas.

The GenBank accession number for the $16 \mathrm{~S}$ rDNA sequence of strain MET12 ${ }^{\top}$ is $A Y 125964$.
Three novel species were fully characterized: Geotoga petraea, Geotoga subterranea and Petrotoga miotherma. Later, Petrotoga mobilis was isolated from a North Sea oilproduction well (Lien et al., 1998). Petrotoga olearia and Petrotoga sibirica were recently isolated from a continental petroleum reservoir in Western Siberia (L'Haridon et al., 2002), from which L'Haridon et al. (2001) also isolated a novel species of the genus Thermosipho. Members of the genus Petrotoga are thermophilic heterotrophs that grow in a broad range of salt concentrations (up to $10 \% \mathrm{NaCl}$ ). During our microbial studies of oil waters originating from offshore reservoirs located in the Gulf of Mexico, we isolated a novel thermophilic strain phylogenetically related to the genus Petrotoga, which we propose to be assigned to a novel species, Petrotoga mexicana sp. nov.

Several strains were isolated from oil/water mixtures taken from production well heads (21-D) in Tabasco (Gulf of Mexico). Samples were collected in sterile plastic bottles and kept at room temperature until used. P. mobilis DSM $10674^{\mathrm{T}}$ and $P$. miotherma DSM $10691^{\mathrm{T}}$ were obtained from the DSMZ, whereas P. olearia DSM $13574^{\mathrm{T}}$ and P. sibirica DSM $13575^{\mathrm{T}}$ were obtained from the Institut Universitaire Européen de la Mer, Plouzané, France. Enrichment cultures were performed in $120 \mathrm{ml}$ serum bottles containing $20 \mathrm{ml}$ medium and inoculated with $2 \mathrm{ml}$ water/oil sample. The medium contained $\left(1^{-1}\right.$ distilled water): $1 \mathrm{~g} \mathrm{NH}_{4} \mathrm{Cl}, 0 \cdot 3 \mathrm{~g}$ $\mathrm{K}_{2} \mathrm{HPO}_{4}, 0 \cdot 3 \mathrm{~g} \mathrm{KH}_{2} \mathrm{PO}_{4}, 0 \cdot 1 \mathrm{~g} \mathrm{KCl}, 0 \cdot 1 \mathrm{~g} \mathrm{CaCl}_{2}, 0 \cdot 2 \mathrm{~g}$ 
$\mathrm{MgSO}_{4} .7 \mathrm{H}_{2} \mathrm{O}, 0.5 \mathrm{~g}$ cysteine hydrochloride, $1 \mathrm{mg}$ resazurin, $30 \mathrm{~g} \mathrm{NaCl}$ and $10 \mathrm{ml}$ trace mineral element solution (Balch et al., 1979). The $\mathrm{pH}$ was adjusted to 7 with $10 \mathrm{M}$ $\mathrm{KOH}$. The medium was boiled under a stream of $\mathrm{O}_{2}$-free $\mathrm{N}_{2}$ gas and cooled to room temperature. Aliquots $(20 \mathrm{ml})$ were dispensed into serum bottles under a stream of $\mathrm{N}_{2} /$ $\mathrm{CO}_{2}(80: 20, \mathrm{v} / \mathrm{v})$ and the sealed vessels were autoclaved for $45 \mathrm{~min}$ at $110^{\circ} \mathrm{C}$. Prior to inoculation, $\mathrm{Na}_{2} \mathrm{~S} .9 \mathrm{H}_{2} \mathrm{O}$, $\mathrm{NaHCO}_{3}$, peptone (Difco), yeast extract and sodium thiosulfate were injected from sterile stock solutions to respective final concentrations of $0.04,0 \cdot 2,0.5$ and $0.02 \%$ $(\mathrm{w} / \mathrm{v})$ and $20 \mathrm{mM} . \mathrm{H}_{2}$ pressure in the gas phase was 2 bars. The bottles were incubated at $60^{\circ} \mathrm{C}$ and three enrichment series were performed in the same culture medium before isolation. Strains were isolated by repeated use of the Hungate roll-tube technique (Hungate, 1969), with medium solidified with $0 \cdot 8 \%$ phytagel (Difco). Serial dilution in roll tubes was repeated at least twice to purify the cultures. Growth experiments were performed in duplicate, using a medium differing from the enrichment medium by the absence of peptone and hydrogen in the gas phase. In addition to the basal medium, $\mathrm{MgSO}_{4} \cdot 7 \mathrm{H}_{2} \mathrm{O}\left(0 \cdot 2 \mathrm{~g} \mathrm{l}^{-1}\right)$ was replaced by $\mathrm{MgCl}_{2} \cdot 6 \mathrm{H}_{2} \mathrm{O}\left(1 \mathrm{~g} \mathrm{l}^{-1}\right)$ and the concentration of yeast extract was increased to $0 \cdot 1 \%$.

The $\mathrm{pH}$, temperature and $\mathrm{NaCl}$ and $\mathrm{MgCl}_{2}$ concentration ranges for growth were determined using basal medium supplemented with $20 \mathrm{mM}$ glucose. The $\mathrm{pH}$ of the medium in Hungate tubes was adjusted by injecting $1 \mathrm{M} \mathrm{HCl}$, $\mathrm{NaHCO}_{3}$ or $\mathrm{Na}_{2} \mathrm{CO}_{3}$ from $10 \%$ sterile anaerobic stock solutions. The characterized strain was subcultured twice under the same experimental conditions before growth rates were determined. All substrates were tested at a final concentration of $20 \mathrm{mM}$ except for formate $(80 \mathrm{mM})$, cellulose, starch and xylan (all $10 \mathrm{~g}^{-1}$ ). Elemental sulfur $(1 \%, \mathrm{w} / \mathrm{v})$, sulfate $(20 \mathrm{mM})$, thiosulfate $(20 \mathrm{mM})$, sulfite $(5 \mathrm{mM})$, nitrate $(10 \mathrm{mM})$ and nitrite $(5 \mathrm{mM})$ were tested as electron acceptors. $\mathrm{H}_{2} \mathrm{~S}$ production was determined photometrically as colloidal CuS by using the method of Cord-Ruwisch (1985). Sensitivity to ampicillin, chloramphenicol, kanamycin, rifampicin and vancomycin was tested at 10, 25, 50 and $100 \mu \mathrm{g} \mathrm{ml}^{-1}$. Controls with ethanol and DMSO (solvents used for chloramphenicol and rifampicin) were performed. Growth was monitored by measuring $\mathrm{OD}_{580}$ and by microscopic observations. Morphological characteristics were determined with an Optiphot (Nikon) phase-contrast microscope. For electron microscopic studies, preparations were negatively stained with sodium phosphotungstate as described by Koussémon et al. (2001). Growth was monitored by measuring $\mathrm{OD}_{580}$ using a UV/ visible spectrophotometer 50 Scan (Varian). Xylanolytic activity was measured as described previously (Fardeau et al., 1997a); the assay was performed by adding dinitrosalicylic acid (Miller, 1959) and the xylose released from xylan degradation was determined from the $A_{540}$. The presence of L-alanine was determined enzymically at $340 \mathrm{~nm}$ as described previously (Fardeau et al., 1997a). Fermentation products were determined by HPLC using a pump (Spectra Series P100; Thermo Separation Products), an automatic sampler (Spectra Series AS100), an Aminex HPX $87 \mathrm{H}(300 \times 7 \cdot 8 \mathrm{~mm})$ column (Bio-Rad), a differential refractometer detector (Spectra System RI-150) and an integrator (Azur Microsoft). An aliquot of $20 \mu \mathrm{l}$ cell-free supernatant was injected into the column, which was maintained at $37^{\circ} \mathrm{C}$. A $2.5 \mathrm{mM} \mathrm{H}_{2} \mathrm{SO}_{4}$ solution was used as solvent with a flow rate of $0.6 \mathrm{ml} \mathrm{min}{ }^{-1}$. The effect of $\mathrm{O}_{2}$ on growth was determined in Hungate tubes containing anaerobic basal medium supplemented with $20 \mathrm{mM}$ glucose. Tubes were inoculated and $20 \mathrm{ml}$ sterile air was added to the gas phase. Cultures were incubated at $55^{\circ} \mathrm{C}$ under agitation (150 r.p.m.). Growth was monitored by turbidity measurements $(580 \mathrm{~nm})$ and by microscopic observations. Experiments were conducted in duplicate and repeated at least twice. The presence of spores was determined by microscopic observation of cultures and pasteurization tests at 80 and $90{ }^{\circ} \mathrm{C}$ for 10 and $20 \mathrm{~min}$.

The $\mathrm{G}+\mathrm{C}$ content of DNA was determined at the DSMZ, using HPLC as described by Mesbah et al. (1989). DNADNA hybridization studies were carried out by the DSMZ as described by De Ley et al. (1970), with the modifications described by Huß et al. (1983) and Escara \& Hutton (1980), using a model 2600 spectrophotometer equipped with a model 2527- $\mathrm{R}$ thermoprogrammer and plotter (Gilford Instruments). Renaturation rates were computed with the TRANSFER.BAS program (Jahnke, 1992). The $16 \mathrm{~S}$ rDNA of strain MET $12^{\mathrm{T}}$ was amplified by adding $1 \mu \mathrm{l}$ cell culture to a thermocycler microtube containing $5 \mu \mathrm{l} 10 \times$ Taq buffer, $0.5 \mu \mathrm{l} 100 \mathrm{nM}$ primers $\mathrm{Fd} 1$ and $\mathrm{Rd} 1,4 \mu \mathrm{l}$ $25 \mathrm{mM} \mathrm{MgCl} 2.6 \mathrm{H}_{2} \mathrm{O}, 0.5 \mu \mathrm{l} 25 \mathrm{mM}$ dNTPs, $0.5 \mu \mathrm{l} \mathrm{Taq}$

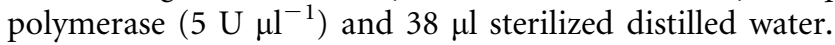
The primers used (Fd1, 5'-AGAGTTTGATCCTGGCTCAG-3'; Rd1, 5'-AAGGAGGTGATCCAGCC-3') were described by Winker \& Woese (1991). The sample was placed in a hybrid thermal reactor thermocycler (GeneAmp PCR System 2400), denatured by heating for $3 \mathrm{~min}$ at $96^{\circ} \mathrm{C}$ and subjected to 30 cycles of $20 \mathrm{~s}$ at $95^{\circ} \mathrm{C}, 30 \mathrm{~s}$ at $52 \cdot 9^{\circ} \mathrm{C}$ and 2 min at $72{ }^{\circ} \mathrm{C}$; this was followed by a final elongation step of $5 \mathrm{~min}$ at $72^{\circ} \mathrm{C}$. PCR products were cloned using the pGEM-T-easy cloning kit (Promega) according to the manufacturer's protocol. Clone libraries were screened by direct PCR amplification from a colony using the vectorspecific primers SP6 ( $5^{\prime}$-ATTTAGGTGACACTATAGAA$\left.3^{\prime}\right)$ and T7 (5'-TAATACGACTCACTATAGGG-3') and the following reaction conditions: $2 \mathrm{~min}$ at $96^{\circ} \mathrm{C}, 40$ cycles of $30 \mathrm{~s}$ at $94^{\circ} \mathrm{C}, 1 \mathrm{~min}$ at $55^{\circ} \mathrm{C}, 3 \mathrm{~min}$ at $72^{\circ} \mathrm{C}$, and a final extension of $10 \mathrm{~min}$ at $72^{\circ} \mathrm{C}$. Plasmids containing inserts of the expected length were isolated using the Wizard Plus SV Minipreps DNA purification system (Promega), according to the manufacturer's protocol. Purified plasmids were sent for sequencing to Genome Express (Grenoble, France). Sequence data were imported into the sequence editor BioEdit version 5.0.9 (Hall, 1999); base calling was examined and a contiguous consensus sequence was obtained. The full sequence was aligned using the RDP Sequence Aligner program (Maidak et al., 2001). The 
consensus sequence was then manually adjusted to conform to the $16 \mathrm{~S}$ rDNA secondary structure model (Winker \& Woese, 1991). A non-redundant BLASTN search (Altschul et al., 1997) of the full sequence through GenBank (Benson et al., 1999) identified its closest relative. Sequences used in the phylogenetic analysis were obtained from the RDP (Maidak et al., 2001) and GenBank (Benson et al., 1999). Positions of sequence and alignment ambiguity were omitted and pairwise evolutionary distances were calculated using the method of Jukes \& Cantor (1969). A dendrogram was constructed using the neighbour-joining method (Saitou \& Nei, 1987). Confidence in the tree topology was determined by using 100 bootstrapped trees (Felsenstein, 1985). rDNA accession numbers of reference organisms are included in Fig. 2. DNA-DNA hybridizations were performed at the DSMZ as described by Koussémon et al. (2001).

Enrichment cultures were incubated at $60^{\circ} \mathrm{C}$ for 1 week. Growth was regarded as positive based on optical density. Microscopic examination of the enrichment culture revealed the presence of rods with an outer, sheath-like structure (toga). Circular, transparent colonies, $2.5 \mathrm{~mm}$ in diameter, appeared after a 6 day incubation at $60^{\circ} \mathrm{C}$ in solidified roll tubes containing phytagel. Three strains of rod-shaped bacteria were isolated that were morphologically and phylogenetically identical. Strain $\mathrm{MET} 12^{\mathrm{T}}$ was characterized further. Individual cells were $0 \cdot 5-0 \cdot 7 \mu \mathrm{m}$ wide and $1 \cdot 4-5 \cdot 0 \mu \mathrm{m}$ long and occurred singly, in pairs or in chains up to $30 \mu \mathrm{m}$ long (Fig. 1a). Cells were surrounded by a sheath-like structure (Fig. 1b). They were motile and no spore formation was detected. Electron microscopy of cell sections exhibited a Gram-negative-type cell wall (Fig. 1c). Strain MET $12^{\mathrm{T}}$ was thermophilic and grew at temperatures ranging from 25 to $65^{\circ} \mathrm{C}$, with an optimum at $55^{\circ} \mathrm{C}$. The isolate was slightly halophilic and grew in the presence of $10-200 \mathrm{~g} \mathrm{NaCl} \mathrm{l}^{-1}$, with an optimum at $30 \mathrm{~g} \mathrm{l}^{-1}$, and $0-200 \mathrm{~g} \mathrm{MgCl}_{2} \cdot 6 \mathrm{H}_{2} \mathrm{O} \mathrm{l^{-1 }}$ (the basal culture medium contained $30 \mathrm{~g} \mathrm{NaCl} \mathrm{l}^{-1}$ ) with an optimum at $1.5 \mathrm{~g} \mathrm{l}^{-1}$. The optimum $\mathrm{pH}$ for growth was $6 \cdot 6$ and growth occurred between $\mathrm{pH} 5.6$ and $8 \cdot 5$. The isolate did not grow under aerobic conditions. Strain MET $12^{\mathrm{T}}$ fermented D-arabinose, cellobiose, fructose, galactose, glucose, lactose, maltose, mannose, raffinose, rhamnose, ribose, starch, sucrose, xylose, xylan and pyruvate. Casamino acids and peptone were only used in the presence of thiosulfate. Glucose was fermented into acetate as the major end product, together with lactate, $\mathrm{H}_{2}$ and $\mathrm{CO}_{2}$. L-Alanine was produced in trace amounts. Substrates that were not used were: acetate, butyrate, formate, fumarate, lactate, malate, butanol, methanol, propanol, methylamine, trimethylamine and $\mathrm{H}_{2}$. The xylanase activity was shown to be endocellular. The isolate used elemental sulfur, thiosulfate and sulfite but not sulfate, nitrate or nitrite as electron acceptors. Strain MET $12^{\mathrm{T}}$ could grow in the presence of $10 \mu \mathrm{g}$ chloramphenicol, kanamycin and vancomycin $\mathrm{ml}^{-1}$ (no growth was obtained at $25 \mu \mathrm{g} \mathrm{ml}^{-1}$ ) and in the presence of $25 \mu \mathrm{g}$ ampicillin and rifampicin $\mathrm{ml}^{-1}$ (no growth was obtained at

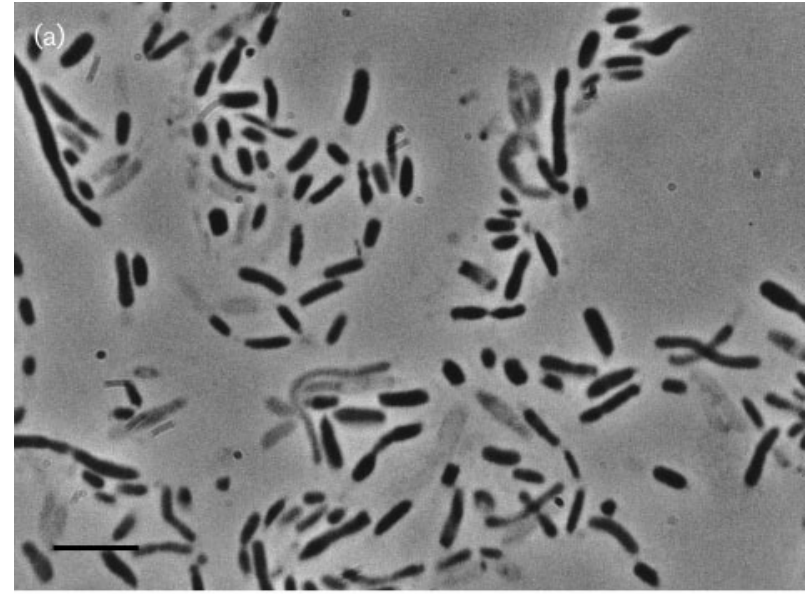

(b)
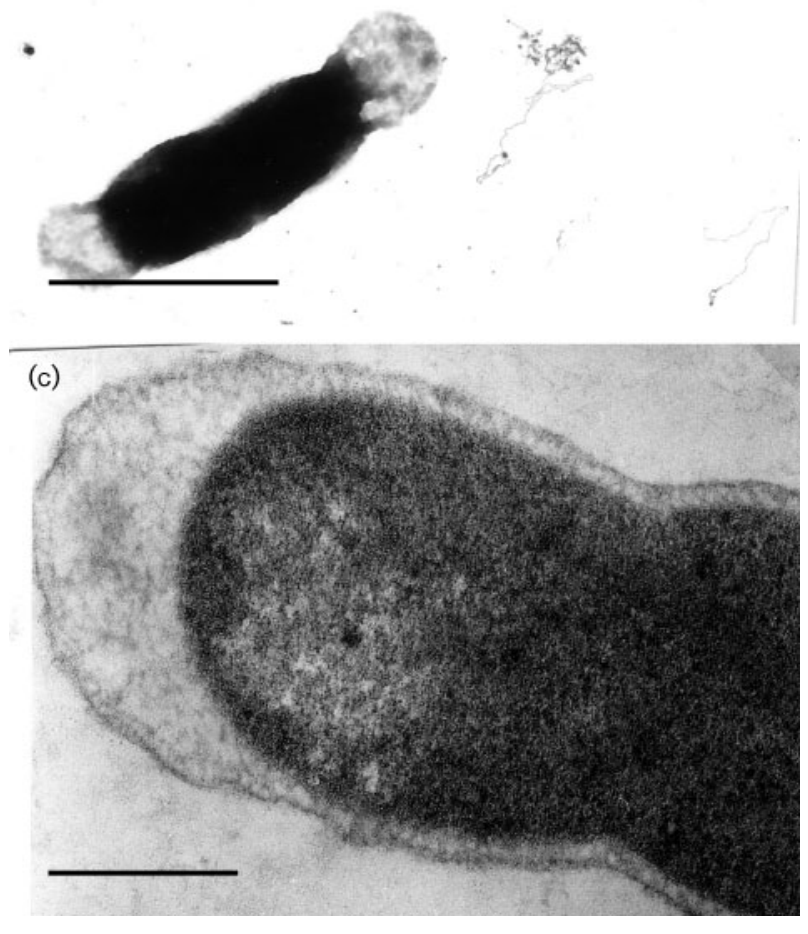

Fig. 1. (a) Phase-contrast micrograph of cells of strain MET12 ${ }^{\top}$; bar, $5 \mu \mathrm{m}$. (b) Transmission electron micrograph of cells showing toga; bar, $2 \mu \mathrm{m}$. (c) Electron micrograph of an ultrathin section showing the Gram-negative cell-wall structure; bar, $0.25 \mu \mathrm{m}$.

$50 \mu \mathrm{g} \mathrm{ml}^{-1}$ ). The $\mathrm{G}+\mathrm{C}$ content of strain $\mathrm{MET}^{2}{ }^{\mathrm{T}}$ was $36 \cdot 1 \mathrm{~mol} \%$ (HPLC).

16S rDNA sequence analysis performed on 1195 unambiguous nucleotides revealed that strain $\mathrm{MET}_{12}{ }^{\mathrm{T}}$ was a 


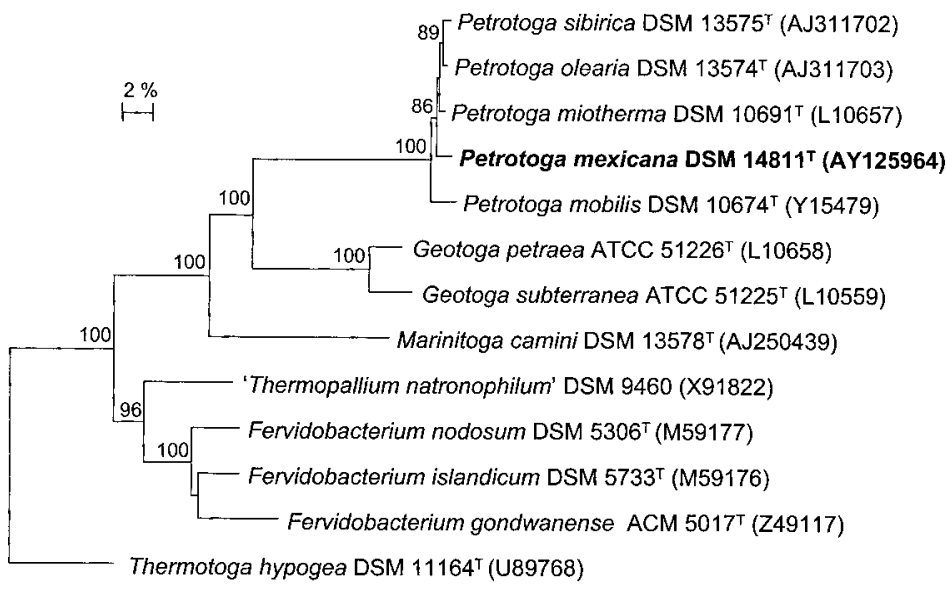

Fig. 2. Phylogenetic dendrogram based on $16 S$ rDNA sequences indicating the position of strain MET12 ${ }^{\top}$ amongst all known species of the family Thermotogaceae. Accession numbers of $16 \mathrm{~S}$ rDNA sequences of reference organisms are included. Bootstrap values, expressed as percentages of 100 replications, are shown at branching points. Only values above $80 \%$ are shown. Bar, 2 nucleotide substitutions per 100 nucleotides.

member of the genus Petrotoga (family Thermotogaceae, order Thermotogales), with P. miotherma Davey et al. 1993 (98.9\% similarity) and P. olearia L'Haridon et al. 2002 (98.6\% similarity) being its closest phylogenetic relatives. Similarities to the two other species of the genus Petrotoga were $98 \cdot 1 \%$ (P. sibirica) and $97 \cdot 6 \%$ (P. mobilis) (Fig. 2). DNA-DNA hybridization studies indicated that strain MET12 $^{\mathrm{T}}$ showed DNA-DNA relatedness of $57 \cdot 1 \%$ to P. mobilis, $48 \cdot 9 \%$ to P. olearia, $53 \cdot 4 \%$ to P. sibirica and $65 \cdot 4 \pm 3 \cdot 2 \%$ to $P$. miotherma.

Moderate to extreme thermophilic anaerobes belonging to the Bacteria and Archaea inhabit oil reservoirs originating from terrestrial or marine environments (Magot et al., 2000). However, more attention has been paid so far to micro-organisms of the domain Bacteria belonging to the families Thermoanaerobiaceae and, particularly, Thermotogaceae, being well-known inhabitants of these terrestrialand marine-subsurface ecosystems (Davey et al., 1993; Fardeau et al., 1997a; Grassia et al., 1996; L'Haridon et al., 2001, 2002; Lien et al., 1998; Magot et al., 2000; Ravot et al., 1995a; Stetter et al., 1993). The order Thermotogales and family Thermotogaceae comprise members of the genera Thermotoga, Fervidobacterium, Thermosipho, Marinitoga, Petrotoga and Geotoga (Alain et al., 2002; Reysenbach, 2001; Wery et al., 2001). Amongst these genera, strains belonging to Petrotoga and Geotoga have been isolated so far only from oil reservoirs (Davey et al., 1993; L'Haridon et al., 2002; Lien et al., 1998). Based on phylogenetic studies, we provide evidence of the existence of a novel isolate (strain MET12 ${ }^{\mathrm{T}}$ ) of the genus Petrotoga that inhabits an oil reservoir in the Gulf of Mexico. This confirms the close ecological relationship between micro-organisms of this genus and the oilfield ecosystem. Strain $\mathrm{MET}_{12}{ }^{\mathrm{T}}$ has $P$. miotherma and P. olearia as its closest phylogenetic relatives, but DNA-DNA hybridization studies (values $<70 \%$ ) with both these species and with P. sibirica and P. olearia allowed its assignment to a novel bacterial species (Wayne et al., 1987). In addition, strain MET12 $2^{\mathrm{T}}$ possesses the highest $\mathrm{G}+\mathrm{C}$ content within the genus Petrotoga (Table 1).

Besides phylogenetic and genomic differences between strain MET $12^{\mathrm{T}}$ and other Petrotoga species, we also found numerous phenotypic differences. Strain MET $12^{\mathrm{T}}$ tolerates the highest $\mathrm{NaCl}$ concentration recorded in the genus (up to $20 \%$, compared with a mean of $10 \%$ for the other species) (Table 1). Strain MET12 $2^{\mathrm{T}}$ differs from P. olearia and $P$. sibirica (L'Haridon et al., 2002) by using thiosulfate as a terminal electron acceptor (Table 1). It also differs from P. mobilis (Lien et al., 1998) by using raffinose, mannose and pyruvate. In contrast to $P$. miotherma, strain $\mathrm{MET12}^{\mathrm{T}}$ is motile. Therefore, the combined phylogenetic, genomic and phenotypic characteristics of strain MET12 ${ }^{\mathrm{T}}$ allow us to assign it to the genus Petrotoga as the type strain of a novel species, Petrotoga mexicana sp. nov.

It is noteworthy that thiosulfate can be used as an electron acceptor and that L-alanine is a minor end product of glucose metabolism by $P$. mexicana. L-Alanine production together with thiosulfate reduction have been found as quite common metabolic features within members of the order Thermotogales (Ravot et al., 1995b, 1996). Because of the position of these micro-organisms in the deepest branches of the phylogenetic tree, L-alanine production from glucose fermentation has been interpreted as a remnant of an ancestral metabolism (Ravot et al., 1996). A thiosulfate-reducing activity shared by several members of this order might (i) help them when oxidizing hydrogen or amino acids such as leucine, isoleucine and valine (Fardeau et al., 1993, 1997b) or (ii) have an undesirable influence on biocorrosion due to sulfide production (Magot et al., 2000). The occurrence of Petrotoga species only in oil reservoirs so far raises questions about (i) their survival in this deep subsurface environment and (ii) their possible indigenicity to this peculiar ecosystem. Further microbial and ecological studies are needed to appreciate their impact in the oilfield environment.

\section{Description of Petrotoga mexicana sp. nov.}

Petrotoga mexicana (mexi.ca'na. N.L. fem. adj. mexicana Mexican, describing the site of sampling of the type strain).

Cells are motile rods, $0 \cdot 5-0 \cdot 7 \times 1 \cdot 4-5 \cdot 0 \mu \mathrm{m}$, with an outer, sheath-like structure (toga), occurring singly, in pairs or in 
Table 1. Differentiating characteristics between strain $M E T 12^{\top}$ and Petrotoga species

Species/strain: 1, P. miotherma (unless otherwise stated, data from Davey et al., 1993); 2, P. mobilis (Lien et al., 1998); 3, P. olearia (L'Haridon et al., 2002); 4, P. sibirica (L'Haridon et al., 2002); 5, P. mexicana sp. nov. (this study).

\begin{tabular}{|c|c|c|c|c|c|}
\hline Characteristic & 1 & 2 & 3 & 4 & 5 \\
\hline Type strain & ATCC $51224^{\mathrm{T}}$ & DSM $10674^{\mathrm{T}}$ & DSM $13574^{\mathrm{T}}$ & DSM $13575^{\mathrm{T}}$ & DSM $14811^{\mathrm{T}}$ \\
\hline Source & Petroleum reservoir & Hot oilfield water & Petroleum reservoir & Petroleum reservoir & Oilfield water \\
\hline Cell size $(\mu \mathrm{m})$ & $0 \cdot 6 \times 2 \cdot 0-7 \cdot 5$ & $0 \cdot 5-1 \cdot 5 \times 1 \cdot 0-50 \cdot 0$ & $0 \cdot 3-0 \cdot 6 \times 0 \cdot 9-2 \cdot 5$ & $0 \cdot 3-0 \cdot 6 \times 0 \cdot 9-2 \cdot 5$ & $0 \cdot 5-0 \cdot 7 \times 1 \cdot 4-30$ \\
\hline No. of cells per sheath & $1-5$ & $1-20$ & $1-2$ & $1-2$ & $1-10$ \\
\hline Motility & $-{ }^{\star}$ & + & + & + & + \\
\hline Spherical bodies & + & - & + & + & + \\
\hline Temperature range $\left({ }^{\circ} \mathrm{C}\right)$ [optimum] & $35-65[55]$ & $40-65[58-60]$ & $37-60[55]$ & $37-55[55]$ & $30-65[55]$ \\
\hline $\mathrm{pH}$ range [optimum] & $5 \cdot 5-9 \cdot 0[6 \cdot 5]$ & $5 \cdot 5-8 \cdot 5[6 \cdot 5-7 \cdot 0]$ & $6 \cdot 5-8 \cdot 5[7 \cdot 5]$ & $6 \cdot 5-9 \cdot 4[8 \cdot 0]$ & $5 \cdot 9-8 \cdot 5[6 \cdot 6]$ \\
\hline $\mathrm{NaCl}$ range $(\%, \mathrm{w} / \mathrm{v})$ [optimum] & $0 \cdot 5-10[2]$ & $0 \cdot 5-9[3-4]$ & $0 \cdot 5-8[2]$ & $0 \cdot 5-7[1]$ & $1-20[3]$ \\
\hline Reduction of $\mathrm{S}_{2} \mathrm{O}_{3}^{2-}$ & $+\dagger$ & + & - & - & + \\
\hline $\mathrm{G}+\mathrm{C}$ content $(\mathrm{mol} \%) \ddagger$ & $34 \cdot 2^{a} / 32^{b} \dagger$ & $34^{a} / 31^{b}$ & $35^{a}$ & $33^{a}$ & $36 \cdot 1^{a}$ \\
\hline
\end{tabular}

${ }^{\star}$ Data from this study.

$\dagger$ Data from Lien et al. (1998).

\$Determined by: $a$, HPLC method; $b$, thermal denaturation method.

chains up to $30 \mu \mathrm{m}$ long. Electron microscopy of cell sections exhibits a Gram-negative-type cell wall. No spore formation is detected. Growth occurs from 25 to $65^{\circ} \mathrm{C}$ (optimum $55^{\circ} \mathrm{C}$ ). Grows in the presence of $10-200 \mathrm{~g} \mathrm{NaCl}$ $\mathrm{l}^{-1}$ (optimum $30 \mathrm{~g} \mathrm{l}^{-1}$ ) and $0-200 \mathrm{~g} \mathrm{MgCl}_{2} \cdot 6 \mathrm{H}_{2} \mathrm{O} \mathrm{l^{-1 }}$ (optimum $1.5 \mathrm{~g} \mathrm{l}^{-1}$ ). Growth occurs between $\mathrm{pH} 5 \cdot 8$ and $8 \cdot 5$ (optimum 6.6). Ferments D-arabinose, cellobiose, fructose, galactose, glucose, lactose, maltose, mannose, raffinose, rhamnose, ribose, starch, sucrose, xylose, xylan and pyruvate. The xylanase activity is endocellular. Glucose is fermented into acetate, lactate, $\mathrm{H}_{2}$ and $\mathrm{CO}_{2}$, with $\mathrm{L}$ alanine as a minor end product. Casamino acids and peptone are used in the presence of thiosulfate. Acetate, butyrate, formate, fumarate, lactate, malate, butanol, methanol, propanol, methylamine, trimethylamine and $\mathrm{H}_{2}$ are not used. Uses elemental sulfur, thiosulfate and sulfite but not sulfate, fumarate, nitrate or nitrite as electron acceptors. Grows in the presence of $10 \mu \mathrm{g}$ chloramphenicol, kanamycin and vancomycin $\mathrm{ml}^{-1}$ and $25 \mu \mathrm{g}$ ampicillin and rifampicin $\mathrm{ml}^{-1}$. The $\mathrm{G}+\mathrm{C}$ content is $36 \cdot 1 \mathrm{~mol} \%$ (HPLC).

The type strain, MET12 ${ }^{\mathrm{T}}\left(=\mathrm{DSM} 14811^{\mathrm{T}}=\operatorname{CIP} 107371^{\mathrm{T}}\right)$, was isolated from an oil well located in the Gulf of Mexico.

\section{Acknowledgements}

We thank Luis Fernández (Instituto Mexicano del Petróleo) for sampling. We also acknowledge financial support to E. M.-T. from Consejo Nacional de Ciencia y Tecnología, Secretaría de Educación Pública and Société Française d'Exportation des Ressources Éducatives. Many thanks to D. Alazard for valuable advice and P. Roger for improving the manuscript.

\section{References}

Alain, K., Marteinsson, V. T., Miroshnichenko, M. L., BonchOsmolovskaya, E. A., Prieur, D. \& Birrien, J.-L. (2002). Marinitoga piezophila sp. nov., a rod-shaped, thermo-piezophilic bacterium isolated under high hydrostatic pressure from a deep-sea hydrothermal vent. Int J Syst Evol Microbiol 52, 1331-1339.

Altschul, S. F., Madden, T. L., Schäffer, A. A., Zhang, Z., Miller, W. \& Lipman, D. J. (1997). Gapped BLAST and PSI-BLAST: a new generation of protein database search programs. Nucleic Acids Res 25, 3389-3402.

Balch, W. E., Fox, G. E., Magrum, R. J., Woese, C. R. \& Wolfe, R. S. (1979). Methanogens: reevaluation of a unique biological group. Microbiol Rev 43, 260-296.

Benson, D. A., Boguski, M. S., Lipman, D. J., Oullette, B. F. F., Rapp, B. A. \& Wheeler, D. L. (1999). GenBank. Nucleic Acids Res 27, 12-17. Cord-Ruwisch, R. (1985). A quick method for the determination of dissolved and precipitated sulfides in cultures of sulfate-reducing bacteria. J Microbiol Methods 4, 33-36.

Davey, M. E., Wood, W. A., Key, R., Nakamura, K. \& Stahl, D. A. (1993). Isolation of three species of Geotoga and Petrotoga: two new genera, representing a new lineage in the bacterial line of descent distantly related to the "Thermotogales". Syst Appl Microbiol 16, 191-200.

De Ley, J., Cattoir, H. \& Reynaerts, A. (1970). The quantitative measurement of DNA hybridization from renaturation rates. Eur J Biochem 12, 133-142.

Escara, J. F. \& Hutton, J. R. (1980). Thermal stability and renaturation of DNA in dimethyl sulfoxide solutions; acceleration of the renaturation rate. Biopolymers 19, 1315-1327.

Fardeau, M.-L., Cayol, J.-L., Magot, M. \& Ollivier, B. (1993). $\mathrm{H}_{2}$ oxidation in the presence of thiosulfate by a Thermoanaerobacter strain isolated from an oil-producing well. FEMS Microbiol Lett 113, 327-332.

Fardeau, M.-L., Ollivier, B., Patel, B. K. C., Magot, M., Thomas, P., Rimbault, A., Rocchiccioli, F. \& Garcia, J.-L. (1997a). Thermotoga hypogea sp. nov., a xylanolytic, thermophilic bacterium from an oilproducing well. Int J Syst Bacteriol 47, 1013-1019.

Fardeau, M.-L., Patel, B. K. C., Magot, M. \& Ollivier, B. (1997b). Utilization of serine, leucine, isoleucine, and valine by Thermoanaerobacter brockii in the presence of thiosulfate or Methanobacterium sp. as electron acceptors. Anaerobe 3, 405-410. 
Felsenstein, J. (1985). Confidence limits on phylogenies: an approach using the bootstrap. Evolution 39, 783-791.

Grassia, G. S., McLean, K. M., Glénat, P., Bauld, J. \& Sheehy, A. J. (1996). A systematic survey for thermophilic fermentative bacteria and archaea in high temperature petroleum reservoirs. FEMS Microbiol Ecol 21, 47-58.

Hall, T. A. (1999). BioEdit: a user-friendly biological sequence alignment editor and analysis program for Windows 95/98 NT. Nucleic Acids Symp Ser 41, 95-98.

Hungate, R. E. (1969). A roll-tube method for the cultivation of strict anaerobes. Methods Microbiol 3B, 117-132.

Huß, V. A. R., Festl, H. \& Schleifer, K. H. (1983). Studies on the spectrophotometric determination of DNA hybridization from renaturation rates. Syst Appl Microbiol 4, 184-192.

Jahnke, K. D. (1992). Basic computer program for evaluation of spectroscopic DNA renaturation data from Gilford System 2600 spectrometer on a PC/XT/AT type personal computer. J Microbiol Methods 15, 61-73.

Jeanthon, C., Reysenbach, A. L., L'Haridon, S., Gambacorta, A., Pace, N. R., Glénat, P. \& Prieur, D. (1995). Thermotoga subterranea sp. nov., a new thermophilic bacterium isolated from a continental oil reservoir. Arch Microbiol 164, 91-97.

Jukes, T. H. \& Cantor, C. R. (1969). Evolution of protein molecules. In Mammalian Protein Metabolism, pp. 211-232. Edited by H. N. Munro. New York: Academic Press.

Koussémon, M., Combet-Blanc, Y., Patel, B. K. C., Cayol, J.-L., Thomas, P., Garcia, J.-L. \& Ollivier, B. (2001). Propionibacterium microaerophilum sp. nov., a microaerophilic bacterium isolated from olive mill wastewater. Int J Syst Evol Microbiol 51, 1373-1382.

L'Haridon, S., Miroshnichenko, M. L., Hippe, H., Fardeau, M.-L., Bonch-Osmolovskaya, E., Stackebrandt, E. \& Jeanthon, C. (2001). Thermosipho geolei sp. nov., a thermophilic bacterium isolated from a continental petroleum reservoir in Western Siberia. Int J Syst Evol Microbiol 51, 1327-1334.

L'Haridon, S., Miroshnichenko, M. L., Hippe, H., Fardeau, M.-L., Bonch-Osmolovskaya, E. A., Stackebrandt, E. \& Jeanthon, C. (2002). Petrotoga olearia sp. nov. and Petrotoga sibirica sp. nov., two thermophilic bacteria isolated from a continental petroleum reservoir in Western Siberia. Int J Syst Evol Microbiol 52, 1715-1722.

Lien, T., Madsen, M., Rainey, F. A. \& Birkeland, N.-K. (1998). Petrotoga mobilis sp. nov., from a North Sea oil-production well. Int J Syst Bacteriol 48, 1007-1013.

Magot, M., Ollivier, B. \& Patel, B. K. C. (2000). Microbiology of petroleum reservoirs. Antonie van Leeuwenhoek 77, 103-116.
Maidak, B. L., Cole, J. R., Lilburn, T. G. \& 7 other authors (2001). The RDP-II (Ribosomal Database Project). Nucleic Acids Res 29, 173-174.

Mesbah, M., Premachandran, U. \& Whitman, W. B. (1989). Precise measurement of the $\mathrm{G}+\mathrm{C}$ content of deoxyribonucleic acid by high-performance liquid chromatography. Int J Syst Bacteriol 39, 159-167.

Miller, G. L. (1959). Use of dinitrosalicylic acid reagent for determination of reducing sugar. Anal Chem 31, 426-428.

Ravot, G., Magot, M., Fardeau, M.-L., Patel, B. K. C., Prensier, G., Egan, A., Garcia, J.-L. \& Ollivier, B. (1995a). Thermotoga elfii sp. nov., a novel thermophilic bacterium from an African oil-producing well. Int J Syst Bacteriol 45, 308-314.

Ravot, G., Ollivier, B., Magot, M., Patel, B. K. C., Crolet, J.-L., Fardeau, M.-L. \& Garcia, J.-L. (1995b). Thiosulfate reduction, an important physiological feature shared by members of the order Thermotogales. Appl Environ Microbiol 61, 2053-2055.

Ravot, G., Ollivier, B., Fardeau, M.-L., Patel, B. K. C., Andrews, K. T., Magot, M. \& Garcia, J.-L. (1996). L-Alanine production from glucose fermentation by hyperthermophilic members of the domains Bacteria and Archaea: a remnant of an ancestral metabolism? Appl Environ Microbiol 62, 2657-2659.

Reysenbach, A.-L. (2001). Order I. Thermotogales ord. nov. Huber and Stetter 1992c, 3809. In Bergey's Manual of Systematic Bacteriology, 2nd edn, vol. 1, p. 369. Edited by D. R. Boone, R. W. Castenholz \& G. M. Garrity. New York: Springer.

Saitou, N. \& Nei, M. (1987). The neighbor-joining method: a new method for reconstructing phylogenetic trees. Mol Biol Evol 4, 406-425.

Stetter, K. O., Huber, R., Blöchl, E., Kurr, M., Eden, R. D., Fielder, M., Cash, H. \& Vance, I. (1993). Hyperthermophilic archaea are thriving in deep North Sea and Alaskan oil reservoirs. Nature 365, 743-745.

Wayne, L. G., Brenner, D. J., Colwell, R. R. \& 9 other authors (1987). International Committee on Systematic Bacteriology. Report of the ad hoc committee on reconciliation of approaches to bacterial systematics. Int J Syst Bacteriol 37, 463-464.

Wery, N., Lesongeur, F., Pignet, P., Derennes, V., Cambon-Bonavita, M.-A., Godfroy, A. \& Barbier, G. (2001). Marinitoga camini gen. nov., sp. nov., a rod-shaped bacterium belonging to the order Thermotogales, isolated from a deep-sea hydrothermal vent. Int J Syst Evol Microbiol 51, 495-504.

Winker, S. \& Woese, C. R. (1991). A definition of the domains Archaea, Bacteria and Eucarya in terms of small subunit ribosomal RNA characteristics. Syst Appl Microbiol 13, 161-165. 